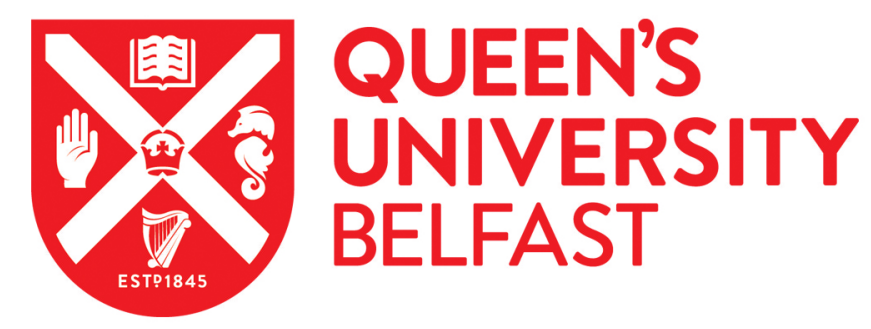

\title{
Promoting leisure-time versus occupational physical activity: socially biased or solutions to closing the socioeconomic gap?
}

Garcia, L., Jones, S., \& Hunter, R. (2021). Promoting leisure-time versus occupational physical activity: socially biased or solutions to closing the socioeconomic gap? British Journal of Sports Medicine. https://doi.org/10.1136/bjsports-2021-104746

Published in:

British Journal of Sports Medicine

Document Version:

Peer reviewed version

Queen's University Belfast - Research Portal:

Link to publication record in Queen's University Belfast Research Portal

Publisher rights

Copyright 2021 the authors.

This is an open access Creative Commons Attribution-NonCommercial License (https://creativecommons.org/licenses/by-nc/4.0/), which permits use, distribution and reproduction for non-commercial purposes, provided the author and source are cited

\section{General rights}

Copyright for the publications made accessible via the Queen's University Belfast Research Portal is retained by the author(s) and / or other copyright owners and it is a condition of accessing these publications that users recognise and abide by the legal requirements associated with these rights.

Take down policy

The Research Portal is Queen's institutional repository that provides access to Queen's research output. Every effort has been made to ensure that content in the Research Portal does not infringe any person's rights, or applicable UK laws. If you discover content in the Research Portal that you believe breaches copyright or violates any law, please contact openaccess@qub.ac.uk. 
Title

Promoting leisure-time versus occupational physical activity: socially biased or solutions to closing the socioeconomic gap?

\section{Authors}

Leandro Garcia ${ }^{1}$

Sophie Jones ${ }^{1}$

Ruth Hunter ${ }^{1}$

${ }^{1}$ Centre for Public Health, Queen's University Belfast, Belfast, UK

\section{Corresponding author}

Leandro Garcia

Centre for Public Health

Institute of Clinical Sciences

Royal Victoria Hospital

Belfast, UK

BT12 6BA

L.Garcia@qub.ac.uk

Published by the British Journal of Sports Medicine. DOI: http://dx.doi.org/10.1136/bjsports-2021-104746 
We read with interest Straker et al.'s editorial ${ }^{1}$ arguing how a focus on leisure-time physical activity is socially biased, and that designing jobs with the right amount and nature of physical activity can correct those biases. We offer here three counter points to encourage a wider discussion of this very relevant and important topic.

Our first point is centred on the fact that Straker et al. compared two different types of physical activity promotion strategies. They wrote that "public health messaging has focused largely on increasing leisure time physical activity", but suggested changes in how work is designed - largely a structural change - could correct socioeconomic biases. We posit the following:

a) For communication campaigns to be effective, the target audience must have the opportunities and means to act upon the information they receive, regardless of being in the leisure or work domain. People from lower socioeconomic backgrounds usually occupy jobs they have less control over, ${ }^{2}$ including on when and how to incorporate physical activity, and thus communication campaigns to change work physical activity would also likely be socioeconomically biased in favour of privileged higher socioeconomic groups.

b) The same logic applied by Straker et al. to structural changes in how work is designed can be applied to structural changes to support leisure-time physical activity for all. Additionally, these changes can benefit those who are not part of the labour market, helping to reduce other social inequalities in health.

Secondly, Straker et al. suggest that we should design "jobs with the 'just right' amount and nature of physical activity." We do agree that jobs should not harm people's health, including by avoiding too much or too little physical activity, and efforts to ensure "just right" physical activity at work should be encouraged and promoted. However, optimal work re-design might not be feasible in all cases, not implemented at the same extent across companies or jobs, or be difficult to regulate and enforce given the number of different jobs and work environment types. Moreover, people in more vulnerable job conditions - who also tend to be part of more vulnerable socioeconomic groups - might have less power to negotiate improvements in their work conditions. Therefore, attempts to design jobs with the "just right" amount and nature of physical activity might unintendedly widen socioeconomic inequalities in health. One can always argue that designing jobs with the "just right" work physical activity will not widen socioeconomic inequalities in health if done right. But the same argument applies to actions to promote leisure-time physical activity.

Thirdly, the approach suggested by Straker et al. does not address the uneven distribution of agency and control people have over their physical activity levels, as the right "amount and nature" of work physical activity is defined by design. This is not different from what happens nowadays, as workers usually do not have control over the (often harmful) physical demands of their jobs. However, those in more vulnerable job (and socioeconomic) conditions have their agency, at and outside work, significantly more curtailed, contributing to systematic health disparities. ${ }^{3}$ Alternatively, reducing work and commuting hours (while keeping wages at levels sufficient to sustain a decent life) would help to give back agency to people over their 
physical activity: when, where, what type, how long for, how intense, and with whom they want to do it (assuming equal access and opportunities are provided to all).

Socioeconomic disparities in leisure-time physical activity practice are well documented, as pointed out by Straker et al. But shifting the focus to the work domain will very likely not resolve the problem. A daylong approach that acknowledges that physical activity is a complex behaviour ${ }^{4}$ and that seeks opportunities across domains, ${ }^{5}$ in light of social justice principles, ${ }^{3,6}$ is needed. The crux of the matter is the unequal distribution of resources, access, and opportunities across our communities, and these disparities are inextricably linked to our physical activity at and outside work (i.e., in the leisure, travel, and home domains). Any physical activity promotion strategies can widen socioeconomic inequalities in health if intentional and sustainable actions tailored to those groups and localities most in need and that close the inequality gap are not implemented.

\section{Contributors}

LG wrote the first draft of the manuscript. All authors contributed to the content of the manuscript and accepted the submitted version of the manuscript.

\section{Funding}

Nothing to declare.

\section{Competing interests}

Nothing to declare.

\section{References}

1. Straker L, Holtermann A, Lee IM, van der Beek AJ, Stamatakis E. Privileging the privileged: the public health focus on leisure time physical activity has contributed to widening socioeconomic inequalities in health. $\mathrm{Br} \mathrm{J}$ Sports Med. 2021;55:525-6.

2. Sekine $M$, Chandola T, Martikainen $P$, Marmot $M$, Kagamimori S. Socioeconomic inequalities in physical and mental functioning of British, Finnish, and Japanese civil servants: role of job demand, control, and work hours. Soc Sci Med. 2009;69(10):1417-25.

3. Lee RE, Cubbin C. Striding toward social justice: the ecologic milieu of physical activity. Exerc Sport Sci Rev. 2009;37(1):10-7.

4. Garcia LMT, Diez Roux AV, Martins ACR, Yang Y, Florindo AA. Development of a dynamic framework to explain population patterns of leisure-time physical activity through agent-based modeling. Int J Behav Nutr Phys Act. 2017;14(1):111.

5. Silva KS, Garcia LM, Rabacow FM, Rezende LF, Sá TH. Physical activity as part of daily living: moving beyond quantitative recommendations. Prev Med. 2017;96:160-2.

6. World Health Organization. Global action plan on physical activity 2018-2030: more active people for a healthier world. Geneva: World Health Organization; 2018. 